\title{
Sosyolojide Müzik: Frankfurt Okulu, Adorno ve Kültür Endüstrisi
}

\author{
Music in Sociology: Frankfurt School, Adorno and Culture Industry \\ Tuğba Aydın Öztürk \\ Dr. Öğr. Üyesi, Üsküdar Üniversitesi, İnsan ve Toplum Bilimleri Fakültesi, Sosyoloji Bölümü \\ email: tugbamusic@gmail.com (DORCID ID: https://orcid.org/0000-0002-7072-5213
}

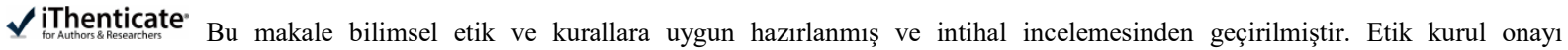
gerektirmemektedir.

Atıf (APA 6)/To cite this article

Öztürk Aydın, T. (2020). Sosyolojide müzik: Frankfurt okulu, Adorno ve kültür endüstrisi. Atatürk Üniversitesi Güzel Sanatlar Enstitüsü Dergisi, 26(45), 527-534. doi: https://doi.org/10.35247/ataunigsed.743676
\end{abstract}

Makale Gönderim Tarihi/Received: 28/05/2020

Makale Kabul Tarihi/Accepted: $14 / 10 / 2020$

Makale Yayın Tarihi/Published: 22/10/2020

Review Article/Derleme Makale

Öz

Bu çalıșmada en önemli felsefi düșünce ekollerinden biri olarak Frankfurt Okulunun tarihsel arka planı, enstitünün faaliyetleri ve enstitüyle ilişkili düşünürlerin çalışmaları ele alınmıştır. Çalışma literatür tarama yöntemi ile hazırlanmış olup, öncelikle Frankfurt Okulu'nun kurulduğu dönemdeki toplumsal ve ideolojik yapı ortaya konmuș ve eleștirel teorinin temelleri açıklanmıștır. Ardından Theodor Adorno'nun felsefeci ve müzikolog kimliği ile Okul'a katkıları ve eserlerinden söz edilmiștir. Adorno ve enstitü müdürü M. Horkheimer'in birlikte geliștirdikleri bir fikir olarak 'Kültür Endüstrisi' konusu ilkeleriyle birlikte incelenmiştir. Son bölümde ise Adorno'nun yaklașımları ve eleștirel teori esas alınarak, popüler müzik endüstrisindeki gelişmeler hem küresel hem Türkiye pazarı için ayrı ayrı anlatılmıştır.

Anahtar Kelimeler: Müzik sosyolojisi, Adorno, Frankfurt Okulu, Kültür Endüstrisi

\begin{abstract}
In this study, the historical background of the Frankfurt School, activities of the institute, and the studies of the thinkers associated with the institute are discussed as one of the essential philosophical Schools of Europe. Firstly, the social and ideological structures of the Frankfurt School are established, and the basics of critical theory are explained. Then, the contributions of Theodore Adorno to the School with his identity as a philosopher and musicologist are mentioned. As an idea that they developed with Adorno and institute director M. Horkheimer, the subject of 'Culture Industry' was examined with its principles. Finally, based on Adorno's critical theory and approach, both global and local developments in the modern music industry are discussed separately.
\end{abstract}

Keywords: Sociology of Music, Adorno, Frankfurt School, Culture Industry

\section{Giriş}

Frankfurt Okulu, Frankfurt Üniversitesi'ne bağlı bir araştırma enstitüsünü temsil etmesinin ötesinde bir düşünceyi, bir geleneği temsil eder. 1920’lerin Avrupa'sında Almanya'da kurulan enstitü, sosyal bilimlerin çeşitli alanlarında çalışan düşünür ve aydınları bir araya getirmiştir. Toplumsal Araştırmalar Enstitüsü (Institut für Sozialforschung), 3 Şubat 1923'de Frankfurt Üniversitesine bağlı olarak, o dönem doktora öğrencisi olan Felix Weil tarafından kurulmuş ve finanse edilmiştir. Enstitünün ilk müdürü Marksist felsefeci Carl Grünberg'dir. Enstitü, sol radikal çevrelerin ortaya koydukları akademik kurumsallaşma çabasının bir sonucu olarak yorumlanır. 1922 yılında düzenlenen 1. Marksist Çalışma Haftası, bu kurumsallaşmanın ilk adımı olarak kabul edilebilir.

Enstitü'nün kurulduğu dönemin siyasal ve toplumsal yapısı oldukça zorlayıcıydı. Bolşeviklerin Rusya'da kazandığı zafer ve Almanya'nın uğradığı yenilgi, okulun ilk dönemine denk gelmekteydi. Bir diğer önemli politik gelişme, 30 Ocak 1933 'de iktidara gelen Adolf Hitler'in genel politikaları ve enstitüyü 'devlete karşı eğilimler taşıdığı’ gerekçesi ile kapatmasıdır. Enstitüyle ilişkili araştırmacıların birçoğu Yahudi ailelerden gelmekteydi ve Alman toplumunun o günlerde içinde bulunduğu durum, pek çok kimse gibi düşünürleri de göçe zorlamışt1.

Tom Bottomore Frankfurt Okulu'ndaki gelişmeleri 4 döneme ayırmaktadır (Bottomore, 2016). 1923- 1933 yılları arasına denk gelen birinci dönemde, araştırma alanları çok çeşitli olup, henüz eleştirel kuram hâkim değildir. Grünberg'in uzmanlık alanlarıyla da ilgili olarak tarih ve iktisat disiplinlerine ait ampirik çalışmalar yürütülür. Ardından felsefeci Max Horkheimer enstitü müdürü olur ve Frankfurt Okulu’nun bildiğimiz anlamındaki düşünsel ve eleştirel yapısı oluşmaya başlar. Horkheimer, açılıș konuşmasında çalışma alanlarının değișeceğinin sinyallerini vermiş ve bu dönemden itibaren felsefe ve eleştirel teori Frankfurt Okulu'nun en önemli konuları haline gelmiştir. 1930'ların başı ile 1950 yılları arasındaki bu dönemde, enstitü ve düşünürler Kuzey Amerika'ya göç eder. 1935'de Sosyal Araştırmalar Enstitüsü New York'a taşınmıştır ve bu durum okulun üretimini ve yayınlarının içeriklerini etkileyecektir.

Bottomore'un ifadesiyle 1950'ye kadar eleştirel kuramın ilkeleri detaylı bir biçimde ortaya konulmuştur. Üçüncü dönemde ise Yeni Sol hareketinin Avrupa ve ardından Amerika'ya yayılmasıyla, yazarların özellikle Marcuse başta olmak üzere fikirleri ve yazdıkları daha fazla sayıda kişiye ulaşmaya başlamıştır. Son olarak, enstitünün 2 
önemli ismi Adorno ve Horkheimer'in ölümüyle, 1970'ler itibariyle Okul'un faaliyetleri son bulur. Ancak öte yandan, Frankfurt Okulu düşünürlerinin ve eleştirel teorinin etkileri, sosyal bilimlerde hala açıkça etkisini korumaya devam eder. Almanca yazılan metinlerin, zaman içinde İngilizce başta olmak üzere diğer dillere çevrilmesi de daha fazla sayıda okuyucuya ulaşmayı sağlamıştır. Löwenthal, (Okul'un) çalışmalarının üzerinden yıllar geçse de eskimeyeceklerini ve bunların gelip geçici konular olmadığını belirtir (Löwenthal, 2003, s. 75).

Max Horkheimer, Herbert Marcuse, Theodor Adorno, Eric Fromm, Frederick Pollock, Leo Löwenthal, Frankfurt Okulu'ndaki temel düşünürlerdir (Wiggershaus, 1995). Kuruma kısa süreli dahil olan ya da hiç dahil olmamış ancak eleştirel teorinin gelişmesinde etkili olan isimlerden bazıları ise, Walter Benjamin, Henryk Grossman, Franz Borkenau, Franz Neuman ve Otto Kirchheimer olarak sayılabilir. Düşünürlerin pek çoğu varlıklı Yahudi ailelerden gelmekteydi. Felsefe, ekonomi, psikoloji, sanat, tarih, estetik alanlarında eğitim görmüsslerdi. Okul'un yayınları incelendiğinde anlaşılacağı üzere, çalışmaların disiplinler arası olduğu görülür. "Alman üniversitesinin sistemine giriş, onların geniş olan ilgi alanlarını bir disiplinle sınıllandırmalarını gerektirecekti. Ayrıca, gerçekleştirmek istedikleri radikal bilim insanı örneği kurulu akademik hiyerarşide pek rağbet gören bir şey değildi” (Jay, 2014, s. 45). Bu sebeple, enstitünün kurucusu Felix Weil'in babası Harman Weil'a bir proje ile gidildi ve kendisi enstitüye bağışta bulundu, ardından Okul için farklı kaynaklardan da ek sermaye sağlandı (Jay, 2014, s. 46). Bu durumda finansal ve fikirsel açıdan bağımsızlık kazanan Okul ve üyeler, Marksizm temelli yazılarını daha rahat bir ortamda yazabilmişlerdir.

Frankfurt Okulu'nun en önemli konuları felsefe bașta olmak üzere, psikanaliz, estetik, müzik, kültür, toplumbilim, siyaset, Marksist ve eleştirel teoridir. Horkheimer'in müdür olmasından sonra sanat ve estetik konularında daha fazla yayın yapılmıştır ve bunda şüphesiz Adorno'nun etkisi büyüktür. Okulun ilk 10 senesinde yürütülen ekonomik, iktisadi temelli ampirik çalışmalar yerini eleştirel yazına bırakır. Özellikle Horkheimer ve Adorno'nun beraber çalıștığı kültür endüstrisi, kitle kültürü, aydınlanma ve modern dünya eleștirisi, negatif diyalektik, sözde bireysellik, geç- kapitalizm, tüketim gibi konular bugün de sosyal bilimlerin sıkça faydalandığı ve esinlendiği konular olmuştur. Konuların çeşitliliği, okulun bağımsız bir kurum olarak daha özgür bir ortamda üretmesi, disiplinler arası çalışmalara açık olunması, 2 büyük Dünya Savaşı arasında kurulan bir kurumun üyelerine sağlayacağı entelektüel deneyim ve bilinç ve son olarak tüketim ve kapitalizmin en çok yaşandığı ülke olan Amerika'ya göç, elbette yazarların bakış açısını etkileyecektir. Eleştirel teori o dönemin içinde bulunduğu siyasal, toplumsal, ekonomik ve kültürel konjonktüründen ayrı düşünülemez.

Frankfurt Okulu düşünürlerinin yazıları günümüzde hala güncelliğini koruyan ve çokça referans olarak kullanılan yazılardır. Geç kapitalizm ve çalışma hayatının ağır şartları arasında kalan birey, standartlaşan sanat ürünleri, yeniden üretim ve artan tüketim bugün yeniden yorumlanmayı bekleyen konuların başında gelir. Bu sebeple hala kuruluşunun üzerinden bir asır geçmiş ve son önemli üyeleri 1970'lerde hayata gözlerini yummuş bir gelenekten bahsedebiliyoruz.

Öte yandan enstitü hem yaşadığı dönemde hem de sonrasında çokça eleştiri almıştır. Düşünürlerin çalışmalarının sadece teorik temelli olması ve deneysel yöntemlerin göz ardı edilmesi, genel bir eleştiridir. Holz, iki farklı konuda Okul'a ve eleş̧irel teori geleneğine eleştiride bulunur. Bunlardan ilki, Okul'un görünüşte etkili bir politik içerik taşımasına rağmen, açık politik tavır almaktan daima kaçınmış olmasıdır. Holz, faaliyetlerini Almanya'dan Amerika'ya taşıyan üyelerin, Nazi uygulamalarından söz etmekten kaçınarak, politika dışı kalma endişelerinden söz eder (Holz, 2014, s. 12).

Holz'un bir diğer eleştirisi ise içerikle alakalıdır. Üyelerin üslup, entelektüel birikim ve edebi açıdan parlak düşünürler olup, kusursuz edebi yazına sahip olmaları, eserlerinin başarısının süregelmesine sebep olmuştur. Hans Heinz Holz'un yazılarının derlendiği Frankfurt Okulu Eleştirisi adlı calışmada, Aydın Çubukçu'nun notlarına göre; sadece eleştiriyi yücelten bu akım, politik örgütlenme ve eylemi ve dolayısıyla dünyayı değiştirme hedefini bir kenara bırakır.

Frankfurt Okulu, düşünürleri ve eleştirel teori çalışmaları eleştirilere maruz kalırken, eleştirel kuram aslında nasıl okunmalıdır? Bottomore (2016), Frankfurt Okulu'nu karmaşık bir görüngü ve onunla ilişkilendirilen toplumsal düşünce tarzını da çok farklı şekillerde yorumlanabilecek bir teori olarak yorumlar. Ancak ilerleyen bölümlerde Adorno'nun negatif diyalektik ve kültür endüstrisi konusunda değinileceği gibi, eleştirel teori; "Faillere içkin anlamda aydınlatıcı ve özgürleştirici bir tür bilgi veren dönüşlü bir teoridir... Eleştirel toplum teorisinin merkezi ideoloji eleştirisidir" (Geuss, 2013, s. 15).

\section{Yöntem}

Araştırmanın Betimsel Model'e dayalı nitel bir araştırmadır. Araştırmada literatür taraması yapılarak, en önemli felsefi düşünce ekollerinden biri olarak Frankfurt Okulunun tarihsel arka planı, enstitünün faaliyetleri ve enstitüyle iliş̧ili düşünürlerin çalışmaları ele alınmıştır. 


\section{Frankfurt Okulu'nda Adorno'nun Yeri ve Önemi}

Theodor Ludwig Wiesengrund 11 Eylül 1903 tarihinde Frankfurt'da doğmuştur. 1930'lardan itibaren dönemin siyasi koşullarından dolayı annesinin kızlık soyadı olan Adorno’yu kullanmış ve eserlerinin çoğunda Theodor W. Adorno adıyla anılmıştır. Babası şarap tüccarı Oscar Wiesengrund ve annesi Cenovalı ses sanatçısı Maris CalvelliAdorno'dur. Ayrica teyzesi profesyonel konser piyanisti Agathe Calvelli- Adorno da onlarla beraber yaşamaktaydı. Bu durumda Theodor Adorno'nun doğumundan itibaren hayatında müzik, sanat ve estetiğin önemli bir yeri olduğu şüphesizdir.

Adorno'nun ilk kez felsefe ile tanışması ise 15 yaşlarındayken, Alman gazeteci- yazar ve sosyolog Siegfried Kracauer ile tanışması ile gerçekleşir. Kracauer ile birlikte klasik Alman felsefesi ve Kant okumaya başlamıştır (Dellaloğlu, 2003, s.13).

1921- 23 yılları arasında Frankfurt Üniversitesinde felsefe, psikoloji, müzik ve sosyoloji üzerine dersler alır. Adorno'dan 8 yaş büyük olan Max Horkheimer, o dönemde aynı kurumda öğretim üyesi olarak çalışmaktadır. Kantçı düşünür Hans Cornelius danışmanlığında "Husserl'in Fenomenolojisi” üzerine doktora tezini yazan Adorno, 1924'de doktor ünvanını kazanır. Ardından müzik ve özellikle bestecilik üzerine eğitim almak üzere 3 yıllığına Viyana'ya gider. Burada Alban Berg ile kompozisyon, Eduard Steuermann ile piyano çalışmış ve Schönberg çevresinin müzik tartışmalarına katılmıştır. Dellaloğlu, Adorno’nun hiçbir zaman çok iyi bir besteci olamadığını ve hatta büyük hayranı olduğu Schönberg ile yıldızının hiç barışamadığını belirtirken konuya kişisel bir yorum getirir. "Belki de bu nedenle çağının en büyük filozoflarından biri oldu” (Dellaloğlu, 2003, s.14).

1931 yılında varoluşçu filozof ve teolog Paul Tillich danışmanlığında “Kierkegaard'ın Estetik Konsepti” üzerine yazdığ 1 tezi ile Privatdozent (Alman üniversitelerindeki bir akademik unvan. Ders verme hakkına sahip, kadrosu olmayan en yüksek doktora derecesidir) unvanını almıştır. Ardından 2 sene süreyle Frankfurt Üniversitesinde öğretim görevlisi olarak çalışmıştır. 1933'de tezinden uyarladığı ilk kitabı "Kierkegaard: Estetik Olanın Kuruluşu" yayımlanır. Bu esnada 1930'ların başından itibaren Toplumsal Araştırmalar Enstitüsü ile yakın ilişkiler içinde olan Adorno, 1938 yılında resmi olarak bu kurumun üyesi olacaktır.

Adorno, 1934- 1938 yıllarını İngiltere'deki Oxford Üniversitesi Merton Kolejde -deneyimli öğrenci- statüsünde çalışarak geçirmiştir. Bu süre boyunca doktora tezi esnasında çalışmalarına başladığı Husserl Fenomenolojisi üzerine kitap projesine devam etmiş ve Horkheimer yönetimindeki Toplumsal Araştırmalar Enstitüsü Dergisi için yazılar yazmıştır. Adorno'nun İngiltere'de kaldığı süre içinde, buradaki felsefecilerle bir bağlantı kurup kurmadığı konusunda kayıt bulunmaz (Dellaloğlu, 2003, s.16). Öte yandan Frankfurt Okulu ve dolayısıyla Adorno'nun yazını hakkındaki ortak görüş; dil konusunda Almanca yazmakta kendilerini daha rahat hissettikleri ve daha net ifade ettikleridir.

Adorno'nun Almanya, Avusturya ve İngiltere dönemlerinin ardından, Enstitü önce İsviçre'nin Cenevre bölgesine ve son olarak Columbia Üniversitesi ile bağlantılı olarak New York'a taşınacaktır. Bir bilim insanı ve araştırmacı olarak, farklı coğrafya ve kültürlerde yaşamak kişiye elbette, değişik bakış açıları kazandıracaktır. Bilim insanı gözlem yapma yeteneğine sahiptir ve her yeni kurum farklı dinamikler taşıdığı için, yazılan eserleri bu etkileri de göz önünde bulundurarak değerlendirmek gerekir.

1938'de Amerika'ya yerleşen Adorno, Horkheimer'in direktörlüğünde çalışmalarına devam eder. Aynı yıl Princeton radyo projesinde yer alır. Aynı yıllarda Berkeley'deki bir araştırma grubuyla önyargı ve otoriteryanizm konuları üzerine yapılan “Otoriteryan Kişilik” projesinde çalışmıştır. Bu çalışma üzerine yazdığı kitabını 1950'de yayinlar.

1944'de Horkheimer ile birlikte yazdıkları en önemli eserlerinden biri olan Aydınlanmanın Diyalektiğini tamamlarlar. 2. Dünya Savaşından dolayı 1947'ye kadar gizlice çoğaltılan kitap, sonradan Hollanda'da basılmıştır. Frankfurt Okulu'nun en etkili çalışmalarından biri olarak kabul edilen kitapta, Adorno ve Horkheimer ilk kez "Kültür Endüstrisi” kavramını kullanırlar. Jay’e göre; Aydınlanmanın Diyalektiği, modernleşmiş bütün toplumlara yönelik mevcut eğilimlerin analizini genişletmiştir. 'Enstitü, çeşitliliğin bir cephe gerisinde, gerçek bireyselliğin kalıntılarını yok etmenin yeni ve kurnazca biçimleriyle çalışan egemenliği fark etmişti’ (Jay, 2001, s. 384).

Adorno 1949'da Felsefe Profesörü unvanını alır ve enstitü 1950'de Almanya'ya geri döner. Burada yine en önemli eserlerinden olan Minima Moralia'yı yazar. Bu kitap, Adorno'nun farklı konulardaki kısa denemelerinden oluşur ve felsefe, günlük yaşam, sanat, müzik, politika, modern toplum, psikoloji, faşizm konularındaki fikirlerini okuyucuya detaylarıyla açıklamaktadır. Adorno kitabının önsözünde felsefeyi bir doğru yaşam öğretisi olarak sunar.

Enstitü'nün yeniden Frankfurt'a dönmesiyle Adorno, idari görevlerde bulunmuş, Horkheimer ve Pollock emekli olduktan sonra da 1959'da müdür olmuştur. Bu süreç içinde Alman besteci Wagner hakkındaki 'Wagner'i Aramak (In search of Wagner)', Avusturyalı besteci ve orkestra şefi Mahler hakkında yazdığı 'Mahler: Müzikal bir Fizyonomi (Mahler: A Musical Physiognomy), Modern Müziğin Felsefesi, Müzik Üzerine Denemeler ve Müzik 
Sosyolojisine Giriş isimli kitapları üzerinde çalışmıştır. Alman filozof Hegel üzerine yaptığı çalışmanın ardından, gençlik döneminde kendisine hocalık ve danışmanlık yapan besteci Alban Berg'in müziğine ve estetik anlayışına dair detaylı bir çalışma sunmuştur (Adorno, 1997). Ayrıca Adorno'nun 1930'larda notlar halinde yazmaya başladığı ancak asla tamamlamadığı Alman besteci Beethoven hakkındaki yazıları, ölümünden sonra Rolf Tiedemann tarafından düzenlenerek, kitap haline getirilmiştir.

Adorno'nun düşün dünyasına kattığı önemli terimlerden ikisi, kitaplarıyla da aynı isimleri taşıyan 'Kültür Endüstrisi' ile 'Negatif Diyalektik'tir. Kültür endüstrisi, bu çalışmanın önemli eleştirel bağlamlarından birini oluşturmaktadır. Adornu'nun kültür endüstrisinden kastı, üretim faaliyeti olarak sunulan bir endüstri formundan daha çok, kültürün ve dolayısıyla bireyin standartlaşması, egemenliğin sermaye ve ideolojik gücü elinde bulunduranlara ait olması ile ilgilidir. Yani, başından beri bir ideoloji eleştirisi vardır. Ayrıca, 'Adorno'nun geliştirdiği felsefi bakış açısı, diyalektik bir toplum kuramı değil, ama sonradan negatif diyalektik diye adlandırdığı şey, yani bütün felsefi konumların ve toplum kuramlarının eleştirisidir” (Bottomore, 2016, s. 21).

Görüldüğü üzere, Adorno hem çok üretken bir yazar hem de birbirinden farklı alanlarda eser verebilmiş bir düşünürdür. Aldığı müzik eğitimi ve bilgisini entelektüel birikimi ile birleştirmiş, eleştirel ve bütüncül bir üslup oluşturmuştur. Bunun yanı sıra, ‘Adorno'nun yaklaşımı fazla deterministik ve elitist olması ya da kavramsallaştırmalarında bazı eksik yönler olduğu doğrultusunda özellikle son birkaç on yılda eleştirilmiştir' (Güven ve Ergur, 2014, s. 4).

Adorno'nun fikirleri 1960'ların Alman üniversite öğrencilerine ilham vermiştir. Ancak yine de bu öğrenci hareketi, Adorno'yu 'teoride eleştirici ancak pratikte konformist -uymac1- bulur (Freyenhagen, 2014, s. 868). Öğrenciler derslerden birini protesto ederler ve Adorno bu olay üzerine polis çağırır. Bu Öğrenci Hareketleri ve üniversitenin içinde bulunduğu durum, Adorno'yu oldukça mutsuz eder. Olaydan bir sene sonra Ağustos 1969'da İsviçre'de hayata veda eder.

\section{Kültür Endüstrisinin İlkeleri}

Çalışmanın bu bölümü, müzik endüstrisini akademik bir arka plan ile açıklamayı amaçlar. Bir sonraki bölümde ise, dünyada ve Türkiye'de müzik ve eğlence endüstrisinde gelişen teknolojik, medya içerikli ve kültürel gelişmelerden kısaca söz edilecektir. Ancak öncesinde, Frankfurt Okulu'nun kültür endüstrisi eleştirel kuramı ana başlıkları ile ele alınacaktır.

Frankfurt Okulu'nun temel eleştirileri, özellikle Grünberg'den sonra Horkheimer'in enstitü müdürü olması ile beraber sanat, kültür ve estetik konuları üzerine yoğunlaşmıştır. Bu konuları, Marksist bakış açısı ile ele almışlar ve modern toplumda kapitalizmin birey ve üretim üzerindeki etkisini tartışmışlardır.

Adorno, endüstri terimiyle doğrudan doğruya bir üretim sürecini değil, kültürel malın standardizasyonu ve dağıtım tekniklerinin rasyonelleşmesini ifade eder (Adorno, 2003, s. 3). Bu cümlede üç farklı konu karşımıza çıkar: kültürel mal, yani kültür ürünlerinin pazar içinde ticari olarak alınıp satılması; standardizasyon ve son olarak rasyonelleşen dağıtım teknikleri.

Adorno'nun burada eleştirdiği konu, kültür ürünlerinin, kendi sektörü içinde, maddi bir değerinin olması ve yaratıcının hayatını idame ettirmesine firsat verecek bir endüstri haline gelmesi, kısaca sanatın bir meslek dalı olarak icra edilmesi değildir. Adorno kültür ürünlerinin üretilmesi ve tüketilmesinde, salt amacin kapitalizme hizmet etme olması fikrine karşıdır: "Kapitalizmde bütün üretim piyasa içindir, mallar insan ihtiyaçlarını ve arzularını karşılamak için değil, kar elde etmek için, daha fazla sermaye elde edinmek için üretilir" (Adorno, 2012, s. 14).

Adorno, sanat ürünlerinin ticari sebeplerle dolaşımda olması ve egemen güçlerin bu yolla ideolojilerini yaymasından duyduğu endişeyi sıkça dile getirir. Bir bakıma bu durum, kültür ürünlerinin anlamını yitirmesine yol açacaktır. Kültür endüstrisinin en önemli eleştirilerinden biri olan standartlaşma sorunu da burada başlar. Pazar içinde alınıp satılan, teknik ve ekonomik güce sahip olanların manipülasyonuna imkân veren, sanat dünyasının yeni ürünleri, standartlaşmış birer meta haline gelmektedir.

Standartlaşma ve seri üretim modern sanayi sonrası toplumlarda öne çıkan kavramlardır (Öztürk, 2015, s. 19). Standardize edilmiş müzik eserleri, radyo ve televizyonların Top 40 listeleri, birbirine benzeyen tür ve formlar, hikâyesi tanıdık olan müzik videoları ya da sinema filmleri üretildikçe, hızlı üretim ve tüketim kaçınılmaz olacaktır. Öte yandan Adorno'nun ifadesiyle; “İzleyici, kendine ait herhangi bir düşünce üretmeye gerek duymamalıdır, ürün her tepkiyi önceden belirler" (Adorno, 2012, s. 69). Kültür endüstrisi hem üreticiyi hem de tüketiciyi seri üretimin dişlisi haline getirmekle meşgul olur.

Adorno'nun kültür endüstrisi tanımında belirttiği 'dağıtım tekniklerinin rasyonelleşmesi' ifadesi, kitle iletişim araçlarının yaygınlaşması ile tekniğin akılcı ve menfaatçi bir biçimde kullanılmasına işaret eder. Kitle, kendisine teknolojik araçlar aracılığıyla ulaşan enformasyonu alır. Bu teknolojiler gazete, dergi, televizyon, radyo, internet medyası, reklamlar vasıtasıyla, ürünler ile kitleler arasında bir iletişim biçimi meydana getirir. 'Rasyonel'; akla 
uygun, aklın kurallarına dayanan, ölçülü, ussal, hesaplı olan anlamlarına gelir ("Rasyonel”, t.y.). Adorno okuyucuya, bu medya araçlarının ve tekniklerin güç sahipleri tarafından hesaplı olarak kullanıldığı mesajını vermektedir. Burada iki farklı güçten söz edilebilir ve ayrıca bunlar çoğu kez bir arada yer alır: ekonomik ve ideolojik güç.

Adorno, tekniğin toplum üzerindeki iktidarının, ekonomik açıdan güçlü olanların iktidarına dayandığından söz ederken (Adorno, 2012, s. 49); Falay, iletişim özgürlüğünün ancak iletişimin fiziksel varlıklarına ve araçlarına sahip olmakla mümkün olacağını belirtir (Falay, 1992, s. 53). İletişim araçları üzerinde tahakkümü olanların, kültür, siyaset, sanat ve günlük yaşam pratikleri üzerinde de söz hakkı doğar. Bu da kitle iletişim araçlarının iletişimdeki hakiki anlamının ve amacının sorgulanmasına yol açar. Adorno’ya göre; “(Kitle iletişim araçlarının) gerçekte ne öncelikle kitlelerle ne de iletişim tekniklerinin gelişimiyle ilgisi vardır, aksine onları dolduran ruhla, sahiplerinin sesiyle ilişkilidir (Adorno, 2003, s. 2).

Tüketici, medya ve reklamlar yoluyla kendisine ulaşan seçeneklerden zevkine en yakın olanı seçer. Aslında bu esnada bile, kendilerine sunulanlar arasından bir seçim yaptıklarını fark etmeleri zordur. Kültür endüstrisinin en büyük eleştirisi, tüketiciyi kasıtlı olarak kendine uydurma çabası taşımasıdır. 'Dinleyici/İzleyici bunu istiyor' yaklaşımı yerel ya da global medyaların en önemli telkinlerinden biridir. Kitleler, bilinçli bir şekilde bu ürünleri tüketmeyi gerçekten istediğinde ise, kültür endüstrisinde reklam haklı bir zafer kazanmıştır. Adorno'ya göre bu; “...tüketicinin sahte olduklarını gördüğü halde, bastırılması zor bir istekle kültür metalarını kullanmaya devam etme isteğidir" (Adorno, 2012, s. 23).

İletişim araçlarının sermaye ve ideolojik güç sahiplerinin elinde olması, bu kurum ve kişilere, kitleleri manipüle etme ve kararları üzerinde söz sahibi olma şansını verir. Tüketiciler, neyi neden tükettiklerini artık fark edemezler, popüler olan, her yerde olan, tüketmeden geri duramayacakları, tanıdık ve bildik olanın tekrarı artık konforlu bir sığınak olmuştur. Tekelleşmiş medya, teknoloji şirketlerinin her geçen gün yenilenen ürünleri ve uygulamalarının zaten tüketicinin ihtiyacı ve talebi olanı sunduğu düşünülür. Ya da Adorno'nun deyimiyle; "Kültür endüstrisi, müşterileri tarafından yönlendirildiğine ve onlara kendi istedikleri şeyleri sunduğuna yeminle inandırmaya çalışır bizi" (Adorno, 2017, s. 209).

Frankfurt Okulu genel yaklaşımı ve özellikle Adorno'nun kültür endüstrisi eleştirisine göre, bu manipülasyonun sebebi özünde, kapitalizmle ilişkilidir. Modern toplum insanları, sanayi devrimi ve geçip giden Dünya savaşlarının ardından, zorlu çalışma şartlarıyla mücadele etmek zorunda kalmıştır. Adorno'nun geç kapitalizm olarak yorumladığı bu dönemde, boş zaman tüketimi, kişiyi rahatlatmaktan ziyade ancak bir sonraki çalışma gününe hazırlar. İnsan bir bakıma otomatik pilotta çalışan bir makine gibidir ve hala üretimin parçası durumundadır. Adorno; 'eğlence geç kapitalizm şartlarında çalışmanın uzantısıdır', der (Adorno, 2012, s. 68). Bu şartlar altında, kişiler benzer hayatlar yaşamaya başlarlar ve bu da birbirine benzeyen tüketim zevklerine dönüşür. Aslında kültür endüstrisi, kendi tüketicisi olan modern bireyi de kendisi üretmektedir (Dellaloğlu, 2018, s. 116). Benjamin, modern dünyada insanın halesini, özgünlüğünü, biricikliğini kaybettiğini söyler. Mekanik üretim çağında her özne bir diğerinin aynısıdır. Dellaloğlu'nun deyimiyle 'herkesin aynı olduğu yerde hiç kimse kalmamıştır' (Dellaloğlu, 2018, s. 22). Modern toplum insanları bir yandan bireyselleşirken bir yandan 'bir'leşir.

Adorno ve Horkheimer, kişilerin birbirlerinin yerine kolayca geçebildiğini düşünerek, özneyi sorgulamışlardır. Kültür dünyasında birbirine benzeyen işler, kişiler ve ürünler imajları biraz değiştirilerek yeniden ve yeniden pazara sunulmaktadır. Benzer ürün, birbirine yakın bir dile sahip medya araçları aracılığıyla, benzer tüketici formatına ulaştığında özgür irade, orijinallik ve yaratımın biricikliği nerede kalır? Adorno, sözde bireyselliği tartışır ve bunu popüler müziğin dikkat çekici özellikleri arasında sayar (Jay, 2001, s.305).

Aşağıda önce dünya genelinde (çoğunlukla ABD ve kısmen Avrupa pazarı) ve sonra Türkiye'de müzik endüstrisindeki gelişmeler ele alınacaktır. Bu gelişmeler, kültür endüstrisi ilkeleri göz önünde bulundurularak yorumlanmaya çalışılacaktır. Sanat dünyasının analizi o toplumdaki üretici, tüketici, medya ve sermaye sahipleri, teknolojik iş birlikleri gibi çok sayıdaki süreci anlamayı gerektirir. Özellikle popüler kültür dünyası, toplumların güncel ekonomik, sosyolojik, siyasal yapısıyla benzer kodları taşımaktadır. Frankfurt Okulu düşünürlerinden Löwenthal; "Sanatı, eleştirel analiz aracılığıyla deşifre edilmesi gereken, toplum içerisinde meydana gelen süreçlerin bir tür kod dili olarak yorumluyoruz", diyerek eleştirel teorinin sanat dünyasına bakış açısını ortaya koyar (Jay, 2001, s.283).

\section{Popüler Müzik Endüstrisine Kısa Bir Giriş}

Müzik dünyası sanat, reklam, medya, halkla ilişkiler, hizmet, teknoloji gibi sektörlerde çalışan çok sayıda kişiyi bir araya getiren ve eğlence sektörünün altında yer alan geniş bir işkoludur. 18. yüzyılın başlarında müzik basım işi ve halka açık biletli konserler bu endüstrinin ticari anlamdaki ilk örnekleri sayılabilir. Bu dönemde konser ve opera destekleyicileri -yani sponsorlar- halk konserleri düzenlemiş ve müzik yayınevleri de yaprak notalarla bu performansları ve enstrümanlar için yapılan adaptasyonlarını dağıtmıştır (Tscmuck, 2001, s. 9). 
Bugün bildiğimiz anlamdaki Global Müzik Endüstrisi, 20. yüzyılın başlarında kitle iletişim araçlarının yaygınlaşması, ses/ kayıt teknolojilerinin gelişmesi ve büyük şirketlerin pazara girmesiyle oluşmaya başlar. Girişimcilik ve yatırımlar müzik dünyasındaki ticari istikrar için önemlidir. Her yeni teknoloji ile kendini yenileyen, değişime uyum sağlayan sektör, yüz yılı aşkın süredir pek çok farklı gelişmeye tanıklık eder.

Profesyonel müzik dünyasında sanatçı tarafından üretilen müzik, dinleyiciye ulaşana kadar çok sayıda süreçten geçer. Yaratım ve teknik süreçlerin tamamlanmasının yanısıra, dağıtım, pazarlama, iletişim, markalama, medya takibi, menajerlik gibi pek çok iş kolunda dayanışmaya ihtiyaç vardır. "Sektör; avukatlar, muhasebeciler, yöneticiler, sekreterler, yazıcılar, bilgisayar programcıları, ajanslar, menajerler, promosyoncular, teknisyenler, prodüktörler, grafik tasarımcılar, besteciler, şarkı yayıncıları, telif ajansları, müzisyenler, şarkıcılar, dansçılar, sahne işçileri, şoförler, gişe çalışanları, DJ'ler, TV prodüktörleri ve direktörler demektir" (Barrow ve Newby, 1994, s. 12). Barrow ve Newby kitaplarında bu sektör çalışanlarını sıraladıklarında yıl 1994'tür. Dijital müzik devrimiyle beraber, yukarıda adı geçen meslek gruplarına yenileri de eklenmiştir. Örneğin 2000'lerden itibaren sosyal medya ve dijital müzik servisleri çalışanları da endüstrinin ayrılmaz parçası olmuştur.

Dünya müzik endüstrisindeki gelişmeler hem teknik hem de sosyo-ekonomik ve toplumsal açıdan kronolojik olarak sıralanabilir. Müzik üzerine çalışmaları olan ekonomi tarihçisi Cyril Ehrlich, müzik dünyasındaki teknolojik gelişmeleri 1877'ye yani klakson ve silindirin kaydına kadar dayandırır. Ardından 'akustik disk' (1907- 1925), 'mikrofon ve elektro kayıt' (1925- 1948), 'teyp kaydı ve uzun plak kaydı' (1948-1983), 'dijital ses ve kompakt disk' (1983- 1998) dönemlerini sıralar. Son olarak, Pattmore bu listeye bilgisayar dosyası (Mp3 gibi) dönemini de ekler (Pattmore, 2009, s. 120).

Bir diğer tarihsel sıralama ise Parker'a aittir. Parker, 'Telif Hakkının Doğuşunu' (1662) kayıt endüstrisi için milat olarak kabul eder. Ardından teknik bir gelișme olarak 'Ses Kaydının İcadı' (1877- 1910) ve ses kayıt telifinin ortaya çıkmasıyla 'Modern Müzik İşinin Kurulması' (1911- 1923) dönemlerinden bahseder. 1920'ler ile 1940'lar arasındaki 'Radyo Çağını', 'Elektronik Devrim' (1946- 1953) takip eder. Aynı zamanda bu dönemde endüstrinin 6 Büyükleri sayılan şirketler olan EMI, CBS, BMG, Polygram, WEA ve MCA'nın, müzik dünyasındaki hegemonyası söz konusudur. Teknik açıdan ise Uzunçalar (Longplay- LP) ve Tekli (Single) dönemidir. Pattmore, bu listede global müzik endüstrisindeki gelişmeleri sıralar ve aslında buradan anlamamız gereken genel anlamda Kuzey Amerika ile Batı Avrupa pazarlarının analizinin yapıldığıdır. Bu sebeple 1950'ler 'Rock, 1960'lar 'Swing' ve 1970'ler 'Pop' müzik türlerinin popüler olduğu dönemler olarak kabul edilir. Elbette dünyanın diğer bölgelerindeki yerel müzik sektörlerinde aynı yıllarda, aynı müzik türlerinin popüler olması beklenemez. Müzik üretim ve tüketimi, endüstrinin ticari kararları kadar, o toplumun ortak beğeni ve estetik zevkleri, sosyo-ekonomik şartlarıyla da ilişkilidir. 1980'li yıllar ilk müzik video kanalı MTV'nin kurulması, şirketlerin birleşmeye gitmesi ve CD dönemi olarak sıralanır. Son olarak 1990’lar internet çağının doğuşu, 2000’ler ise ekonomik kriz olarak listelenmiştir (aktaran Pattmore, 2009).

2010'lu yıllardan itibaren dünyada ve kademeli olarak Türkiye müzik endüstrisinde dijital teknolojilere uyum sağlanmaya başlanmış, güçlü plak şirketleri başta olmak üzere endüstri yeni gelir modelleri yaratmaya başlamıştır. Özellikle dijital müzik servislerinin sırasıyla downloading (indirme) ve streaming (dinleme) sistemleri dinleyici tarafından ilgi çekmeye başlamıştır. Fiziksel albüm satışlarının tarihin tozlu sayfalarına karışmasını takiben dijital dünyada müziği üretmek ve tüketmenin anlam dünyası da değişmiştir.

2019 yılı itibariyle dünyadaki en güçlü plak şirketi sayısı üçe (Sony BMG, Universal Music, Warner Music Group) inmiş ve bu şirketler hala dünyadaki toplam müzik endüstrisinin \%80'inden fazlasını elinde tutmaktadır (McDonald, 2019). Bu anlamda hala hegemonik bir güç olarak şirketleşme ve karşısında alternatif bir yaratım alanı olan bağımsızların mücadelesi mevcuttur. Bugünün müzik dünyasından söz edildiğinde teknoloji ile iç içe geçmiş ve dijital dünyanın girişimcilerinin aktif olarak rol aldığı şirket ve şahısları görürüz. Özellikle Z kuşağının müziğin yeni paydaşları olarak, dinleyici olma kriterleri, sosyal medyayı kullanma biçimleri, tüketici alışkanlıkları, müzik endüstrisi literatürünün en fazla öne çıkan konularıdır (Walzer, 2017; Golden, 2019; Negus, 2018)

Türkiye müzik endüstrisi tarihine kısaca baktığımızda, özellikle teknolojik gelişmelerin dünya ile eş zamanlı olmadığı görülür. Fonograf dünyadan yaklaşık 20 yıl sonra 1895'de Türkiye'ye gelir (Ünlü, 2004). Ardından gramofon ve plak dönemi başlar. Plakçılıkta ilk yıllarda kayıtlar İstanbul'da yapılıp, Almanya'da çoğaltılır. Müzik endüstrisinde teknolojiye sahip olmak, her zaman pazar hâkimiyeti açısından avantaj olmuştur. Türkiye'de profesyonelleşmiş müzik endüstrisi 1930'lara doğru, mikrofonla ses kaydı yapabilme ve Columbia, Odeon, Sahibinin Sesi gibi bilinen müzik şirketlerinin İstanbul'da iş yapmaya başlaması ile başlar. Teknolojinin yaygınlaşması ve yatırımların artması, müziğin endüstrileşmesinin temelidir.

Radyo 1920'lerin sonunda İstanbul ve Ankara'da yayınlarına başlamış olsa da ilk 10-15 yıllık süreç içinde yalnızca maddi durumu yeterli kişiler bundan faydalanır. Radyonun kitleselleşmesi 1950'lerin sonunu bulacaktır. 1990'lardan itibaren özel radyoların açılmasıyla, radyoda popüler müziklerin hâkimiyeti başlar. 1960'lar kaset ve gazino dönemi, 1968'de TRT'nin açılmasıyla TV dönemi başlar. Aynı şekilde 1990'larda özel televizyonların 
sayısı günden güne artar. Dünyadaki MTV'ye karşılık gelecek şekilde 1994'de Türkiye'nin ilk video müzik kanalı Kral TV yayına başlamıştır (Aydın, 2010). 1990'ların sonunda CD ve 2000'lerin başı itibariyle yasal olmayan Mp3 paylaşımları endüstrinin ihtiyaçlarını farklı bir boyuta taşır. Dijital müzik dönemiyle birlikte, Türkiye müzik dünyası büyük maddi kayıplar yaşar. 2013-2014 yıllarından itibaren ise dünyadaki dijital platformlarla yapılan anlaşmalar ve meslek birliklerinin çalışmaları ile Türkiye müzik dünyasının dijitalleşme çabası emekleme dönemine girmiş olur.

Müzik endüstrisinin en önemli özelliklerinden biri ‘popülerlik' olgusudur. Popüler olan şimdinin, çağdaş olanın temsilidir. Köken olarak ise bir anda ortaya çıkmak, patlamak sözcüklerinden gelir. Toplumlarda çoğu kez bir eserin sanatsal ve estetik değerinden ziyade, bilinirliği ve kulağa tanıdık gelmesi kabul görür. Aslında popüler kültür, egemen kültüre bir tepki olarak ortaya çıkmıştır, yerel ve bölgesel kültürleri içerir ve daha çok şimdiki yaşamın kültürünü ifade eder. Fakat zamanla eğlence endüstrisinde egemen olan kültür, popüler kültür olmuştur.

Popüler işleri popüler kılan özellikler nelerdir? Öncelikle büyük şirketler, dünyanın farklı yerlerindeki farklı zevklere sahip kişiler için belli sınırlılıkta olacak şekilde alternatif işler pazara sunarlar. Pop bir müzik türü olarak çok sayıda alt türlere aittir. Albüm satın alan, konserlere giden ya da özetle müzik endüstrisinin müşterisi durumunda olan kitle büyük oranda gençlerdir. Yapımcıların büyük bütçelerle pazara sunduğu müzisyenler, medyada çok sık yer alarak dinleyiciye ulaşırlar. Radyo, TV programları, açık hava reklamları, turneler, sosyal medya tanıtımları gibi tüm geleneksel ve yeni yöntemler kullanılarak, kişilerin popüler olması sağlanır ya da var olan popülariteleri bu yollarla korunur. Adorno' ya göre ise sanat ile reklam arasındaki fark artık ortadan kalkmıștır (Jay, 2001, s. 167).

Global ve yerel müzik endüstrisi raporları analiz edildiğinde, en çok dinlenilen ve satın alınan müzik eserlerinin, popüler şarkıcı ve gruplara ait olduğu görülür. Sanat dünyası, aktörlerini popüler kimseler üzerine kurgular ve bu kişileri star konumuna yerleştirerek onlara cazibe katar. Az sayıda star, dünya müzik endüstrisindeki satışlar üzerinde söz sahibidir. Popüler müzisyenler ve müzik şirketleri, müziğin gideceği yöne karar verir ve yeni trendler yaratırlar. Bu şekilde, birbirine benzeyen ve özgünlükten uzak işler ortaya çıkmış olur. Adorno kültür endüstrisinin, kültürün iki uzlaşmaz öğesini yani sanat ve eğlenceyi tek bir amaca indirgemesine ve kültür endüstrisinin bütünselliğine tabi kılmış olmasına karşıdır. Adorno bu formülün yinelemeye dayandığını ifade eder (Adorno, 2012, s. 67).

\section{Sonuç Yerine}

Müzik eserleri ve popüler ögeler medya yoluyla yeniden üretilerek, tüketici karşısına çıkarılır. Tüketim, popüler kültürün en önemli uzanımıdır. Dijital müzik devrimiyle birlikte, albüm satışları neredeyse sona ermiştir. Bunun yerine sanatçılar kısa süreli aralıklarla single çıkarır ve dijital platformlara yüklerler. Video içerikli web sitelerine her gün binlerce yeni video ve şarkı yüklenmekte, popüler sosyal medya uygulamalarının içerikleri her saniyede değişmektedir. Böylesine hızlı tüketimin olduğu bir ortamda, yapılan işlerin önemi ve değeri sorgulanmalıdır. Başarının birinci önceliği, bu hız çemberinin dışına düşmemek ve her yeniliğe hızla adapte olmaktan geçer. Adorno'nun sözde bireysellik ve Baudrillard'ın bireyin biçimsel özgürlüğü olarak nitelediği modern bireyin, bu hızlı üretim ve tüketim çağında kendi bağımsız düşüncesinden söz edilebilir mi? Birey, neyi neden tükettiğinin tam bilincinde midir?

Müzik endüstrisinin kitle iletişim araçları ile iş birliği yapması, ticari başarı için gereklidir. Öte yandan medyada yer almak, bütçe ve sosyal sermaye gerektirir. Yani, müzik şirketleri ya da bireysel olarak müzisyenler medyanın tanıtım gücünden faydalanmak isterse, bunun için finansal bütçe ayırmalı ve kişiler arası iletişim becerilerini kullanmalıdır. Medya, tüketiciler üzerinde manipülatif bir etkiye sahiptir. Çoğu kez, izleyici/dinleyici üzerinde kültürel tahakküm kurmanın yolu, güçlü ekonomik bağlantılara sahip olmak ve medyayı etkin kullanmakla gerçekleşir.

Müzik dünyası hem global hem de yerel pazarlarda, büyük ölçekli müzik, medya ve teknoloji șirketlerinin kontrolündedir. "Güçlü kuruluşlar ekonomik etkinliklerini güçlendirmek için yoğunlaşmaya ve holdingleşmeye çalışır. Yoğunlaşma herhangi bir verili sektördeki mülkiyetin belli başlı birkaç şirketin tekelinde olmasıdır" (Laughey, 2010, s.80). Az sayıda satıcının, çok sayıda alıcıya ulaştığı ve satılan ürünlerin birbiriyle benzerlik gösterdiği bu pazar oligopolistik ekonomi modeliyle açıklanır. İktisadi açıdan, büyük ve orta ölçekli müzik şirketlerinin, popüler sanatçılarla çalışma ya da çalıştıkları sanatçıyı popülerleştirme, medya kanalları ile iletişime geçme ve iş birliği yapma, teknolojiyi etkin kullanma ve daha büyük pazarlara ulaşma gibi avantajları vardır. Ancak popüler müzisyen ve güçlü şirketlerin elinde bulundurduğu bu avantaj, bağımsız müzisyen ve müzik şirketleri için dezavantaj sağlayabilir. 


\section{Kaynakça}

Adorno, T. W. (1997). Alban Berg: Master of the smallest link. Cambridge: Cambridge University Press.

Adorno, T. W. (2003). Kültür endüstrisini yeniden düşünürken. (B. O. Doğan, Çev). Cogito, 1-5. Erişim adresi: http://blog.aku.edu.tr/ometin/files/2013/12/k\%C3\%BClt $\% \mathrm{C} 3 \% \mathrm{BCr}-\mathrm{end} \% \mathrm{C} 3 \% \mathrm{BC}$ strisinin-yeniden-d $\% \mathrm{C} 3 \%$ $\mathrm{BC} \% \mathrm{C} 5 \% 9 \mathrm{~F} \% \mathrm{C} 3 \% \mathrm{BCn} \% \mathrm{C} 3 \% \mathrm{BC}$ rken-Adorno.pdf

Adorno, T. W. (2012). Kültür endüstrisi kültür yönetimi. İstanbul: İletişim Yayınları.

Adorno, T. W. (2017). Minima moralia. İstanbul: Metis Yayınları.

Aydın, T. (2010). 1990 yılı ve sonrası Türkiye'de kitle iletişim araçları ve müzik medya üzerindeki etkisi (Yüksek lisans tezi). YÖK tez veri tabanından erişildi (Tez No. 262220).

Barrow, T., \& Newby, J. (1994). Inside the music business. New York: Roudledge.

Bottomore, T. (2016). Frankfurt okulu ve eleştirisi. İstanbul: Say Yayınları.

Dellaloğlu, B. (2003). Bir giriş: Adorno yüz yaşında. Cogito Özel Sayl: Adorno: Kitle, Melankoli ve Felsefe, 36 , 13- 36. Erişim adresi: https://issuu.com/buyukkutuphane/docs/cogito_dergisi_-_say_36___yaz_2003

Dellaloğlu, B. (2018). Frankfurt okulu'nda sanat ve toplum. İstanbul: Say Yayınları.

Falay, N. (1992). Kitle iletişim teorileri. İstanbul Üniversitesi İletişim Fakültesi Dergisi, O(1-2), 47-58. Erişim adresi: https://dergipark.org.tr/tr/download/article-file/213143

Freyenhagen, F. (2014). Adorno's politics: Theory and praxis in Germany' 1960's. Philosophy and Social Criticism, 40(9), 867-893. Erişim adresi: https://core.ac.uk/download/pdf/74370243.pdf

Geuss, R. (2013). Eleştirel teori: Habermas ve Frankfurt okulu. İstanbul: Ayrıntı Yayınları.

Golden, A. (2019). Generation z re-defining the business of music. Music Business Journal. Erişim Adresi: http://www.thembj.org/2019/09/generation-z-re-defining-the-business-of-music/

Güven, U. Z., \& Ergur, A. (2014). Dünyada ve Türkiye'de müzik sosyolojisinin yeri ve gelişimi. Sosyoloji Dergisi, 3(29), 1- 19. Erişim adresi: https://dergipark.org.tr/tr/download/article-file/4888

Holz, H. H. (2014). Frankfurt okulu eleştirisi. İstanbul: Evrensel Basım Yayın.

Jay, M. (2001). Adorno. (Ü. Oskay,Çev.). İstanbul: Der Yayınları.

Jay, M. (2014). Diyalektik imgelem Frankfurt okulu'nun tarihi ve çalışmaları (1923-1950). İstanbul: Ayrıntı Yayınları.

Laughey, D. (2010). Medya çalışmaları teoriler ve yaklaşımlar. İstanbul: Kalkedon Yayıncılık.

Löwenthal, L. (2003). Theodor Adorno’yla anılarım. Cogito Özel Sayl: Adorno: Kitle, Melankoli ve Felsefe, 36 , 65-75. Erişim adresi: https://issuu.com/buyukkutuphane/docs/cogito_dergisi_-_say_36_-_yaz_2003

McDonald, H. (2019, 29 Temmuz). How the big record labels became the big three [Blog yazıs1]. Erişim Adresi: https://www.thebalancecareers.com/big-three-record-labels-2460743

Negus, K. (2018). From creator to data: The post-record music industry and the dijital conglomerates. Media, Culture and Society, 41(3), 367-384. doi: https://doi.org/10.1177/0163443718799395

Öztürk, T. A. (2015). Müzik icracılarının kültür endüstrisi ve dinleyici beklentileri arasında yeni medya bağlamında uyum stratejileri (Doktora tezi). YÖK tez veri tabanından erişildi (Tez No. 393637).

Pattmore, D. (2009). Selling sounds: Recordings and the record business, the Cambridge companion to recorded music. N. Cook and E. Clarke (Eds.). Cambridge: Cambridge University Press.

Rasyonel. (t.y.). Türk Dil Kurumu güncel Türkçe sözlük içinde. Erişim adresi: https://sozluk.gov.tr/

Tscmuck, P. (2001). Creativity and innovation in the music industry. Vienna: Springer.

Ünlü, C. (2004). Gel zaman git zaman. İstanbul: Pan Yayıncılık.

Walzer, D. A. (2017) Independent music production: How indivituality, technology and creative entrepreneurship influence contemporary music industry practices. Creative Industrial Journal, 10(1), 21-39. doi: https://doi.org/10.1080/17510694.2016.1247626

Wiggershaus, R. (1995). The Frankfurt school, Its history, theories and political significance. USA: Polity Press. 